\title{
THE RELATIVE EFFECT OF LOW IMPACT AEROBIC ON THE RISK OF FALLING IN THE ELDERLY AS COMPARED TO TRADITIONAL GYM
}

\author{
Ninik Nurhidayah \\ Department of Occupational Therapy, School of Health Polytechnics, \\ Surakarta
}

\begin{abstract}
Background: Gym is recomended for the elderly to maintain good health. Aerobic is a type of gym which result in high oxygen uptake. However, aerobic can lead to high risk of falling and consequent injury to the elderly. Recently, a new modified aerobic known as low impact aerobic was introduce to the elderly. This study aimed to determine the relative effect of low impact aerobic on the risk of falling in the elderly as compared to traditional gym.

Subjects and Method: This was a randomized control trial (RCT) conducted at the elderly integrated post Kedung Gobyak, Sobokerto, Ngemplak, Boyolali. A sample of 30 elderly people were randomized into two groups: 15 elderly people in the low impact aerobic group and 15 elderly people in the traditional elderly gym. The independent variable was type of gym. The dependent variable was falling risk, which was measure by Tinetti test. Aerobics was performed 3 times a week with 20-30 minutes duration per session for 4 weeks. Difference in mean of falling risk between the two groups was tested by independent t-test.

Results: As a result of randomization, there was no statistically significant difference $(\mathrm{p}=0.851)$ in mean of falling risk before gym between low impact aerobic group and elderly group. There was no statistically significant difference $(\mathrm{p}=0.672)$ in mean of falling risk after gym between low impact aerobic group $($ mean $=25.93 ; \mathrm{SD}=4.57)$ and elderly group $($ mean $=25.27 ; \mathrm{SD}=$ 3.94).

Conclusion: Low impact aerobic can be practiced by the elderly to maintain good health as an alternative to the traditional elderly gym since it does not increase falling risk as compared to the elderly gym.
\end{abstract}

Kewords: elderly, low impact aerobic, elderly gym, falling risk

Correspondence: Ninik Nurhidayah. Department of Occupational Therapy, School of Health Polytechnics, Surakarta.

Email: niniknurhidayah@gmail.com. Mobile: +6281567987031. 